\title{
NANOECONOMICS AND INNOVATIVE MARKETING AS FACTORS OF SUSTAINABLE DEVELOPMENT IN GLOBAL ENVIRONMENT
}

\author{
Tetiana Ostapenko', Maksym Kolesnyk ${ }^{2}$
}

\begin{abstract}
The relevance of the research topic is determined by the fact that the world is changing towards the environmental situation deterioration: ozone holes, air pollution and water contamination, food crisis and many natural disasters. These problems must be solved at all possible levels - global, local and individual. The object of the research is defined as influence of nanoeconomics on the sustainable development of different national economics and world economy in general. The peculiarities of the global environment in the context of sustainable development should be outlined at these levels and mainly at the level of nanoeconomics. The purpose of the study is to identify the individual innovative factor in global sustainable development. The subject of research is nanoeconomics in the framework innovative marketing of global sustainable development. The main research methods are a systematic approach and structural analysis, comparison and observation, mathematical methods (regression analysis, in particular). The results of the study include the assessment of three sustainable development components (economic, ecological and social), their impact on the quality of the global environment, nanoeconomics and innovative marketing. The results obtained can be used in the elaboration of state programs for sustainable development with the focus on the global, national and individual levels as well as on the education and upbringing in different educational establishments from preschool institutions to corporate universities. Sustainable development of the countries studied is determined by the high rates of the environmental protection policy. Although the environmental pollution is still ongoing, there is a tendency of a less hazardous impact on the natural world. Waste is recycled rather than utilized, which is an act of the consumer system improvement when not only brand new goods and services are purchased but also those that can easily be processed. Such policy reflects an economically frugal approach to the environmental development. To sum up, the social component is crucial for sustainable development since all the countries under study are highly developed and the poverty is not a decisive factor of the development with the food problem solved long ago. However, helping those in need becomes the basis for the governmental and the private sector activity. These issues are resolved with the implementation of the Agenda 2030. Hence, the global sustainable development goals are subject to the economic, social and environmental factors of nanoeconomic evolution in the countries studied.
\end{abstract}

Key words: global environment, sustainable development, nanoeconomics, innovative marketing, global sustainable development goals, agenda.

JEL Classification: Q56, Q01, M31

\section{Introduction}

The article is devoted to the issue of global changes in the planet's ecosystem that must be solved by means of various levers (global, national, local and personal) affecting the sustainable development and determining the progress of the global environment with the main approaches to environmental protection challenges through economic and social mechanisms.

\footnotetext{
Corresponding author:

${ }^{1}$ National Aviation University, Ukraine.

E-mail: ostapenco@ukr.net

ORCID: https://orcid.org/0000-0003-2032-1365

${ }^{2}$ National Aviation University, Ukraine.

E-mail: maks.vit.koles@gmail.com

ORCID: https://orcid.org/0000-0003-0814-4220
}

The research is based on the role of individualistic and innovative approaches to environmental challenges since the issue of reducing ozone holes should be resolved not only at the UN level but also at the level of individuals, who should synergistically prevent the activation of emissions into the atmosphere. However, such individual innovative behavior must be motivated at the national and local levels. 
The problems which are explained in the article by influence of the nanoeconomics on sustainable development. Pollution of environment is defined by enterprise factor and by the individual causes. We have chosen three countries: Singapore, Finland and USA. These states are the firsts in the level of competitiveness and in the level of development of nanoeconomic system. Also these countries elaborate waste, using ecologic, economic and social aspects. The world goals of the sustainable development help the states and individuals form clear environment and improve the quality of people's life.

It is intended to determine the conditions of nanoeconomics' influence on the sustainable development at the global level. The aim is achieved through the following tasks' accomplishment: nanoeconomics' identification as a sustainable development factor, exposition of the global sustainable development conditions, the description of environmental, economic, and social components of sustainable development in such countries as: Singapore, Finland, and the United States.

The systemic approach was used to characterize sustainable development. The structural analysis was applied in assessing the levels of the global environment while the method of comparison was directed at determining the characteristic features of the sustainable development system in the studied countries-Singapore, Finland and the United States. The mathematical methods allowed to calculate the correlation link between nanoeconomics and the indicators of the environmental situation in the studied countries.

The problems of sustainable development are revealed in various works of national and foreign scientists, but the issue of the nanoeconomics' impact on the sustainable development is not sufficiently covered in scientific publications at different levels.

Thus, scholar J. Mensah (Mensah, 2019) highlights the content of sustainable development, especially its significance, history, principles and the impact on human activity. Researcher K. Hylton (Hylton, 2019) estimates the extent of the legislation formation with regard to sustainable development and its adjustment policies at the state level. Scientists S. Brodhag and S. Thaliere (Brodhag \& Taliere, 2006) describe the strategies of sustainable development and conditions of their formation at the level of the enterprise and national economy. Experts M. Browning and A. Rigolon (Browning \& Rigolon, 2019) concentrate on the issues of green space and its impact on the scientific progress in different countries.

Nanoeconomics as the lowest level of the economic system contributes to the sustainable development formation while the issues of nanoeconomic development are highlighted in the works of such scientists as: K. Arrow, G. Kleiner (Kleiner, 1997),
O. Inshakov (Inshakov, 2007), I. Manakhova (Manakhova, 2011), B. Schmarzo and others.

The sustainable development issues at the nanoscale are not considered in scientific sources, the relevance of which is recognized. Moreover, a human being as an individual factor of sustainable development is not singled out. Besides, strategic state and local conditions are analyzed, but the importance of an individual person is not assessed. Such researches will be further conducted as we must raise the generation that economically treats the environmental problems of all humankind and local areas (with their atmospheric, water, soil characteristics) as well as their own homes, which should also be environmentally friendly.

\section{International approaches to definition of sustainable development}

Natural conditions have a huge positive impact on human development and welfare. The concept "natural conditions" encompasses the absorption functions, i.e., air and water as the environments that absorb humanmade pollution and resource functions as the production is based on the use of forests, fishing and mining. The protection of absorption functions is important for human health. The protection of production or resource functions is crucial for the economic security of those whose lives depend on these resources. Highquality natural conditions affect welfare indirectly as an important component of sustainable industrial production and service delivery (Nair Chandran, 2020).

Sustainable development results in the formation of natural conditions in different countries of the world and in the global environment on the whole. Economies that receive a significant part of their income from natural resources are unable to sustain the growth, compensating for the deterioration of natural conditions by the accumulation of physical capital (Asian Development Bank, 2017). As a rule, the impoverishment of the natural environment causes the greatest damage to the poor segments of the population, whose incomes often depend on natural resources and who have few opportunities to replace them with other types of resources. The approaches to the growth in the global environment that focus on the environmental quality and resource efficiency have a positive impact on the savings, investments, economic growth and human welfare especially in a long-term perspective.

Stable development foresees the big quantity of external environment factors existence. This environment experiences the active influence of innovative factors, as the problem of environment custody directly depends on quality of innovations. Among all of such innovative factors, the authors highlighted nanoeconomics and innovation marketing. Nanoeconomics, as the economy of innovative 
individuals and innovative marketing as innovative concept of market manufacturing, is decisive in national innovative systems formation - nanoeconomics defines personal factor of such systems as innovative marketing - permanence (sustainability) of provision, implementation and promotion conditions of new (nanoeconomics in particular) products and processes.

Sustainable development determines the existence of nanoeconomics when people create the conditions in which they exist and then these conditions determine the quality of their life. It is well known that the quality of individuals' life depends on the decisions made at the marketing level, state level and at the level of the global environment. The latter form the appropriate policy and are characterized by the use of the sustainable development management levers.

The efficiency of certain corrective measures will depend on the nature of the problem as well as on the economic and institutional situation.

It is to be noted that a clear international environmental policy is formulated in Resolution 38/361 of the United Nations General Assembly and is regulated by the World Commission on Environment and Development (WCED). According to the United Nations Commission on Sustainable Development (CSD) (1992), its goal is to meet the needs of the modern society without compromising the ability of future generations to meet their own needs. The theory of sustainable development is an alternative to the paradigm of economic growth which disregards the environmental threats caused by the development in compliance with the extensive model (Sidelnikova, 2014). This model is common in developing countries where individuals suffer from the increased use of space, territory, air and water resources, thus trying to regulate all these factors at the global level. So, at the United Nations General Assembly Special Session 119 ("Rio + 5", June 1997) it was noted that all public sectors should contribute to the development and implementation of the sustainable development strategy. The session required all countries to formulate and develop national sustainable development strategies that reflect the contributions and responsibilities of all the parties concerned by 2002 .

The latest achievement of the United Nations in the study of sustainable development is the final document of "Rio + 20", entitled “The Future We Want". The United Nations Conference on Sustainable Development or Rio +20 took place in Brazil, June 2012. It was a forum aimed at debating and developing initiatives within the concept of sustainable development. The issues tackled upon the vital activity of individuals and various effects on the quality of nanoeconomics. A particular individuals form innovative approaches to marketing complex realization.

In the study, nanoeconomics is defined as an integral part of social production (or economics as a whole), the productive force of which is the individuals who acquire the skills of economic behavior, make the best management decisions in the process of learning and training and ensure high competitiveness and its experience acquisition sharing in the economic environment on the basis of nanotechnologies application.

Global sustainable development challenges must be adjusted and solved through the implementation of the future global agreement (Coates \& Nghi, 2017).

In 2015, the Sustainable Development Agenda was adopted by the relevant UN conference. Seventeen goals were announced for people and our planet. The Sustainable Development Goals are a universal call for action in order to put an end to poverty, protect the planet and improve the lives and prospects of everyone and everywhere. Seventeen goals were adopted by all UN Member States in 2015 as a part of the 2030 Agenda for Sustainable Development which set out a 15-year plan to achieve the Goals (Estrada, 2017).

Nowadays, a certain progress is being made in many spheres, but, in general, appropriate measures to meet the Goals have not yet been taken to reach the scope and extent required. The year 2020 became a period of decisive steps to achieve the goals by 2030 .

With less than ten years left to achieve the sustainable development goals, world leaders at the SDG Summit in September, 2019 announced a Decade of Action and Progress in the favor of sustainable development and pledged to mobilize financial resources, improve operational efficiency at the national level and strengthen institutions to achieve the goals by the target date of 2030, leaving no one behind.

The UN Secretary-General called on all public sectors to unite efforts for a decade of action and progress at three levels (Obama, 2017):

- global action to ensure more effective leadership, a wider range of resources and smarter solutions for sustainable development goals in connection with realization of innovative marketing programs;

- local action encompassing the required transition in politics, budget, institutions and the regulatory framework of governments, cities and local authorities when innovative marketing is used to promotion and realization of stable development programs on local level;

- collective action, including the initiatives of youth, civil society, the media, the private sector, unions, academia and other parties concerned to provide and maintain an ever-growing dynamics towards implementing necessary transformations.

As we can see, the Agenda is spelled out for both global environment and nanoeconomics and in innovative marketing complex realization. Many countries achieve the Goals in different ways (Feng Wang Yong \& Baochang, 2012), the list of which is given below: 


\begin{tabular}{|l|l|l|l|}
\hline Goal 1 & No poverty & Goal 10 & Inequality abolition \\
\hline Goal 2 & No hunger & Goal 11 & Sustainable cities and local authorities \\
\hline Goal 3 & Good health and well-being & Goal 12 & Responsible consumption and production \\
\hline Goal 4 & Quality education & Goal 13 & Stable climate \\
\hline Goal 5 & Gender equality & Goal 14 & Life under water \\
\hline Goal 6 & Clean water and sanitation & Goal 15 & Life on land \\
\hline Goal 7 & Affordable and clean energy & Goal 16 & Peace, justice and powerful institutions \\
\hline Goal 8 & Decent work and economic growth & Goal 17 & Partnerships \\
\hline Goal 9 & Industry, innovations, and infrastructure & & \\
\hline
\end{tabular}

\section{Influence of nanoeconomics on sustainable development in Singapore, Finland and the USA}

It is worth considering the system of the sustainable development issues and solutions in the leading countries. Though being developed, Singapore, Finland and the United States are facing many grave challenges. These countries solve environmental pollution problems from the standpoint of helping developing countries. However, the issues of sustainable development are also their great concern. So, it is necessary to study the environmental situation in these countries and analyze its effect on nanoeconomics.

Thus, Singapore is a country with a developed economy, with well-handled issues of efficient production and responsible consumption, a country with extensive IT capabilities, mechanical engineering and responsible agriculture. The country invents new technologies to improve the life and well-being of the population and uses the innovative marketing levers.

Waste management is one of the indicators in assessing the quality of the environment and usage of innovative marketing in their recycling. Therefore, the statistics on this component in the life of society are given in Table 1.
As we can see in Table 1, the largest amount of waste is generated in construction, ferrous metals, cardboard and paper spheres. It is to be noted that these are the industrial spheres where not an individual becomes a producer of waste but enterprises and it can be recycled with the appropriate technologies available. Thus, plastics, that do not decompose in the environment or decompose over long periods of time, have the lowest rate of recycling while most wastes are sent for conservation.

In addition, waste produced by human activityfoods (organic waste), textiles, leather and horticultural products - is not processed intensively enough: $18 \%$, $4 \%$ and $73 \%$, respectively. The country has a responsible attitude to waste sorting and a personal responsibility for it. There are state legislative acts that support this attitude to waste generation and disposal. Training takes place from school and lasts a lifetime. Awareness of one's own contribution to the environment becomes the basis for the responsible life of an individual Singaporean.

The social component of sustainable development in Singapore includes employment and pay, as shown in Table 2.

Table 1

Waste Management Statistics and its Recycling in 2019

\begin{tabular}{|l|c|c|c|c|}
\hline \multicolumn{1}{|c|}{ Waste type } & Waste generation (tons) & Waste recycling (tons) & Recycled \% & Total accumulated (tons) \\
\hline Construction and demolition & 1440 & 1434 & $99 \%$ & 6 \\
\hline Ferrous metals & 1278 & 1270 & $99 \%$ & 561 \\
\hline Paper / cardboard & 1011 & 449 & $44 \%$ & 893 \\
\hline Plastic & 930 & 37 & $4 \%$ & 607 \\
\hline Foods & 744 & 136 & $18 \%$ & 139 \\
\hline Timber & 438 & 289 & $66 \%$ & 107 \\
\hline Horticultural products & 400 & 293 & $73 \%$ & 226 \\
\hline Ash / dirt & 252 & 25 & $10 \%$ & 3 \\
\hline Textile / leather & 168 & 6 & $4 \%$ & 2 \\
\hline Used slag & 129 & 127 & $98 \%$ & 64 \\
\hline Nonferrous metals & 126 & 124 & $99 \%$ & 2 \\
\hline Glass & 75 & 11 & $14 \%$ & 195 \\
\hline Scrap metal & 33 & 31 & $94 \%$ & 2984 \\
\hline Others (pebbles, ceramics) & 210 & 15 & $7 \%$ & \\
\hline Totaling & 7234 & $59 \%$ & \\
\hline
\end{tabular}

Source: $w w w . t a b l e b u i l d e r . s i n g s t a t . g o v . s g$ 
Vol. 7 No. 3, 2021

Table 2

Employment Rates in Singapore in 2019 and 2020

\begin{tabular}{|l|c|c|c|c|}
\hline \multicolumn{1}{|c|}{ Work, employment } & Unit & The last period & The latest data & The previous period \\
\hline Employment rate (quarter) & $‘ 000$ & September 2020 & 3.613 & 3.645 \\
\hline Employment changes (quarter) & $‘ 000$ & September 2020 & -32.1 & -113.5 \\
\hline Unemployment & \% to the workforce & September & 3.6 & 2.8 \\
\hline Total workforce & ‘00 & 2019 & 3.740 & 3.675 \\
\hline
\end{tabular}

Source: www.tablebuilder.singstat.gov.sg

Table 3

Gross Monthly Income from Work (USD)

\begin{tabular}{|l|l|l|l|l|l|l|l|l|l|l|}
\hline 2009 & 2010 & 2011 & 2012 & 2013 & 2014 & 2015 & 2016 & 2017 & 2018 & 2019 \\
\hline 2927 & 3000 & 3299 & 3480 & 3705 & 3770 & 3949 & 4056 & 4232 & 4437 & 4563 \\
\hline
\end{tabular}

Source: www.tablebuilder.singstat.gov.sg

As we see, employment in this country is quite high and the unemployment rate is very low amounting for $3.6 \%$. Employment is growing from year to year. So, this shows a positive trend in the development of human potential and nanoeconomics. Monthly indicators of salaries are also growing, so salaries have almost doubled in the period between 2009 and 2019, as evidenced in Table 3.

Such figures show that poverty is uncommon in the country, and the average monthly income is growing. It is to be pointed out that the state also influences the circumstances regarding environmental protection. Moreover, there are a number of documents that regulate these issues: the code of activity to obtain a license for a general waste collector; a general waste collector's license; a safe guide for general waste collectors; an application document for used oil products processing.

The correlation analysis of the study proves a close link between the environmental component and the nanoeconomics in Singapore since these aspects are resolved at the nanoscale when a person either suffers from excess waste in the environment or affects its collection, accumulation and disposal. In its turn, such human activity affects global recycling rates and also the formation of the global environment for sustainable development.

The natural environment protection in Finland is the key to the development of the national economy. The country with a strong forestry sector, represented by the paper and furniture industries, is very active in protecting the whole sphere from pollution, deforestation and careless treatment.

Statistics on environmental protection are represented in Table 4.

As we can see in Table 4, the environmental costs on protection measures are imposed on the sphere of consumption, the activity of enterprises with regard to the turnover of fixed and working capital and investment policy. The consumer sector is the most productive one in terms of environmental costs and for innovative marketing complex realization. Meanwhile, it is the sector of nanoeconomics where revenues and payments are directed at the sustainable development.

Table 4

Environmental Protection Costs in 2016-2018 (million EUR)

\begin{tabular}{|l|c|c|c|}
\hline \multicolumn{1}{|c|}{ Sector } & 2015 & 2017 & 2018 \\
\hline Public & $\ldots$ & $\ldots$ & $\ldots$ \\
\hline Consumption & 333 & 376 & 388 \\
\hline Investments & 16 & 21 & 20 \\
\hline Working capital and equity & & & \\
\hline (paid-received) & 326 & 346 & 352 \\
\hline Industry & $\ldots$ & $\ldots$ & $\ldots$ \\
\hline Totaling & 2754 & 2750 & 2939 \\
\hline
\end{tabular}

Source: $w$ ww.stat.fi

Either enterprises or individuals consume as little energy as possible positively affecting nanoeconomic factors of the national economic development.

Furthermore, Finland is a country with responsible waste management, as described in Table 5.

Table 5

Waste Production and Recycling in Finland in 2018

\begin{tabular}{|l|c|c|}
\hline \multicolumn{1}{|c|}{ Waste type } & Waste production & Waste recycling \\
\hline Total waste & 128252 & 125234 \\
\hline Chemical waste & 538 & 519 \\
\hline Metal waste & 887 & 200 \\
\hline Paper and cardboard waste & 625 & 563 \\
\hline Timber waste & 4371 & 3269 \\
\hline Animal and plant waste & 1039 & 952 \\
\hline $\begin{array}{l}\text { Household and mixed } \\
\text { waste }\end{array}$ & 2262 & 2165 \\
\hline Dirt, ash & 999 & 777 \\
\hline Mineral waste & 116303 & 115365 \\
\hline Other waste & 1428 & 1230 \\
\hline Hazardous waste & 1899 & 1736 \\
\hline
\end{tabular}

Source: $w w w . s t a t . f i$ 
The social component of sustainable development in Finland is determined by the pay indicators and the unemployment rate. It is well known that the pay has been rising for ten years and the unemployment rate has also risen but not significantly.

As indicated in Table 6, the average pay determines the gradually rising income levels and rather low extreme poverty rates. It is necessary to admit that the higher the income level of an individual representative of the nation is, the more money is spent on luxury goods and technologies that allow to bring the environment into a balanced state.

The unemployment figures in Finland are at the level of $6.2-7.4 \%$. They are not as low since in Singapore they are within $3 \%$. Unemployment is known to be the cause of poverty although unemployment benefits are paid in developed countries; still Finns are seeking employment at the earliest opportunity in order to live a good quality lifestyle.

The correlation analysis proves that Finland has the closest link between nanoeconomics and the environmental component to become a country with high competitiveness, due to its nanoeconomics based on human development in the favorable sustainable environment where a person, as a member of a highly developed society, has a chance to grow and improve a quality of life. The latter is provided by individuals and enterprises. So, the sustainable development is ongoing along with the growing importance of nanoeconomics in the national and global environment.

Another country under review is the United States which is a powerful player in the global markets of goods and services in general. Statistics on the environmental situation in this country are limited, thus OECD data are used for the study.

A large country has a huge amount of waste, as indicated in Table 7. The waste disposal and recycling rates are also indicators of sustainable development. The country promotes waste sorting and environmental friendliness at the federal level. Moreover, the index of political measures is rather high while environmental taxes are paid fairly and are used for sustainable development needs.
The average annual pay in the United States is kept within 92,400 USD in the private sector and within 97,100 USD - in the public sector that amounts to 7,600 USD per month. These are the significant indicators with a positive effect on the national nanoeconomics. More and more Americans set up businesses and pay taxes contributing to the country's development although more and more private companies have recently suspended their activities.

The high unemployment rate underlying the poverty poses a big challenge for the United States. Its indicators are at $6.9 \%$ level in 2020 which turned out to be a severe pandemic period. Meanwhile, ordinary Americans keep losing their jobs.

The United States is a country with the lowest link between nanoeconomics and environmental protection. Therefore, the US has developed the document entitled "The United States Global Development Policy and Agenda for Sustainable Development 2030”. Its basic provisions cover global development goals and their conformity to American realities.

\section{Conclusions}

The approaches to the growth in the global environment that focus on the environmental quality and resource efficiency have a positive impact on the savings, investments, economic growth and human welfare especially in a long-term perspective.

The efficiency of certain corrective measures will depend on the nature of the problem as well as on the economic and institutional situation.

The latest achievement of the United Nations in the study of sustainable development is the final document of "Rio + 20", entitled "The Future We Want". The United Nations Conference on Sustainable Development or Rio +20 took place in Brazil, June 2012. It was a forum aimed at debating and developing initiatives within the concept of sustainable development. The issues tackled upon the vital activity of individuals and various effects on the quality of nanoeconomics.

In the study, nanoeconomics is defined as an integral part of social production (or economics as a whole),

Table 6

Monthly Pay in Finland in 2010-2019 (EUR)

\begin{tabular}{|l|l|l|l|l|l|l|l|l|l|}
\hline 2010 & 2011 & 2012 & 2013 & 2014 & 2015 & 2016 & 2017 & 2018 & 2019 \\
\hline 3006 & 3080 & 3184 & 3259 & 3302 & 3342 & 3371 & 3396 & 3455 & 3532 \\
\hline
\end{tabular}

Source: www.stat.fi

Table 7

The Environmental Situation in the USA in 2010-2018

\begin{tabular}{|l|c|c|c|c|c|c|c|}
\hline \multicolumn{1}{|c|}{ Indicator } & 2012 & 2013 & 2014 & 2015 & 2016 & 2017 & 2018 \\
\hline Local waste production (tons) & & 231380 & 243471 & 237782 & 242055 & 242935 & - \\
\hline Sustainable environmental policy (index) & 3.17 & 2.67 & 2.58 & 2.69 & & & - \\
\hline Environmental tax revenue (mil. USD) & 0.779 & 0.755 & 0.742 & 0.728 & 0.713 & & - \\
\hline
\end{tabular}

Source: www.statista.com 
the productive force of which is the individuals who acquire the skills of economic behavior, make the best management decisions in the process of learning and training and ensure high competitiveness and its experience acquisition sharing in the economic environment on the basis of nanotechnologies application.

Sustainable development of the countries studied is determined by the high rates of the environmental protection policy. Although the environmental pollution is still ongoing, there is a tendency of a less hazardous impact on the natural world. Waste is recycled rather than utilized, which is an act of the consumer system improvement when not only brand new goods and services are purchased but also those that can easily be processed. Such policy reflects an economically frugal approach to the environmental development and approaches to its provision with innovative marketing measures, which add the stability to innovative development of nanoeconomics.

To sum up, the social component is crucial for sustainable development since all the countries under study are highly developed and the poverty is not a decisive factor of the development with the food problem solved long ago. However, helping those in need becomes the basis for the governmental and the private sector activity. These issues are resolved with the implementation of the Agenda 2030. Hence, the global sustainable development goals are subject to the economic, social and environmental factors of nanoeconomic evolution in the countries studied.

\section{References:}

Asian Development Bank (2017). Firing Up Regional Brain Networks: The Promise of Brain Circulation in the ASEAN Economic Community. Available at: www.adb.org/publications/regional-brain-networks-aseanFINAL. pdf\&usg=AFQjCNHJ48TKpgrlukM23U26i-h5UhDxEow

Brodhag, C. and Taliere, S. (2006). Sustainable development strategies: tools and policy coherence. Natural Resource Forum, 30, 136-145. DOI: 10.1111/narf.2006.30.issue-2

Browning, M. and Rigolon, A. (2019). School green space and its impact on academic performance: a systematic literature review. International Journal of Environmental Research and Public Health, 16 (3), 429. DOI: 103390/ ijerph16030429.

Coates Brendan and Nghi Luu. China's Emergence in Global Commodity Markets, June 1, 2017. Available at: www.static.treasury.gov.au/uploads/sites/I/2017/06/0I-China-Commodity-demand.pdf

Estrada Francisco (2017). A Global Economic Assessment of City Policies to Reduce Climate Change Impacts, Nature Climate Change, no. 7, 403-406. Available at: nature.com/articles/nclimate330I

Feng Wang Yong Cai and Baochang Gu. (2012). Population, Policy and Politics: How Will History Judge China's One-Child Policy? Population and Development Review. 38 Issue Supplement, 115-129.

Hylton, K. N. (2019). When should we prefer tort law to environment regulation? Washburn Law Journal, 41, 515-534. Sustainability 2019, 11, 294.

Inshakov, O. V. (2007). Nanoekonomika i ekonomicheskaya genetika [Nanoeconomics and Economic Genetics]. Volhohrad. (in Russian)

Kleiner, G. B. (1996). Sovremennaya ekonomika Rossii kak «ekonomika fizicheskih lits [Modern Economy of Russia as an Economy of Physical Entities]. Economic Issues. Issue 4. (1997 ed.) Nanoekonomika. Anatomiya esche odnogo strannogo rossiyskogo fenomena [Nanoeconomics. Anatomy of One More Strange Russian Phenomenon]. Judicial News. Issue 22. (in Russian)

Manakhova, I. V. (2011). Nanoekonomika: mnogourovnevyiy podhod kissledovaniyu ekonomicheskih otnosheniy [Nanoeconomics: Multi-level Approach to Researching Economic Relations]. Saratov University News. Economics. Management. Law. Issue 2. Vol. 11. (in Russian)

Mensah Justice (2019). Sustainable Development: Meaning, History, Principles, Pillars and Implications for Human Action: Literature Review. Cogent Social Sciences, volume 5, issue 1. Available at: www.Tandfonline.com/ doi/full/10.2080/23311886.2019.1653531

Nair Chandran (2020). Derzhava staloho rozvytku. Maibutnie uriaduvannia, ekonomiky ta suspilstva [The State of Stable Development: The Future of Government, Economy and Society]. Kyiv: Our Format. (in Ukrainian)

Obama Barak (January 13. 2017). The Irreversible Momentum of Clean Energy. Science 355, no. 6321. Available at: www.science.sciencemag.org/content/355/6321/126

Sidelnikova, V. K. (2014). Stalyi rozvytok ekonomiky Ukrainy v umovakh hlobalizatsii [Stable Economic Development of Ukraine in Global Conditions]. H.S. Skovoroda Kharkiv National Pedagogical University. Issue 14. (in Ukrainian)

Schmarzo Bill. Mastering Nanoeconomics in the Era of Digital Transformation. “The Economic Data, Analytics Digital Transformation". Available at: http://www.Linkedin.com/puls/mastering-nanoeconomics-era-digitaltransformation-bill-schmarzo 


\section{APPENDICES}

SINGAPORE

\begin{tabular}{|c|c|c|}
\hline Year & GDP per capita (dependent), USD & Production of waste tons (the independent variable) \\
\hline 2020 & 95603 & 7234 \\
\hline 2019 & 101458 & 6937 \\
\hline 2018 & 100092 & 6830 \\
\hline 2017 & 94941 & 6548 \\
\hline 2016 & 89386 & 6437 \\
\hline 2015 & 86975 & 6029 \\
\hline 2014 & 84423 & 6038 \\
\hline 2013 & 83002 & 5856 \\
\hline 2012 & 82065 & 5623 \\
\hline 2011 & 80052 & 5464 \\
\hline 2010 & 75294 & 6321 \\
\hline
\end{tabular}

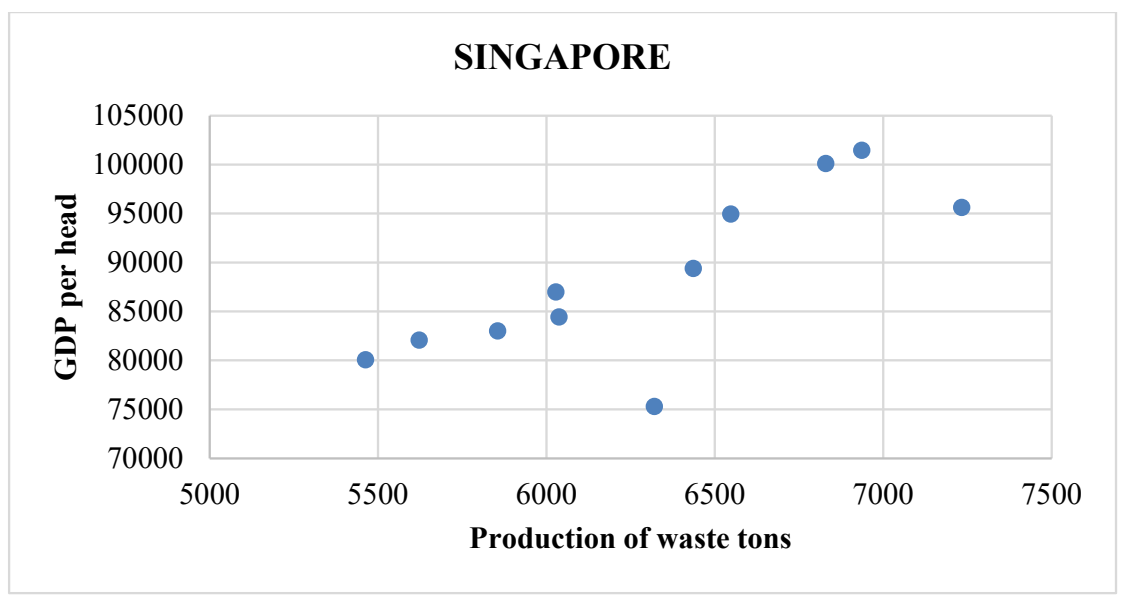

GDP $=12.06 \cdot$ Prod.waste +12497.5

The coefficient of correlation $=0.79$ and the coefficient of determination $=0.62$ indicate the presence of a linear connection between the variables. The independent variable coefficient is statistically significant with $\mathrm{p}$-value $=0.004$

FINLAND

\begin{tabular}{|c|c|c|}
\hline Year & GDP per capita (dependent), USD & Production of waste tons (the independent variable) \\
\hline 2020 & 50748 & 128252 \\
\hline 2019 & 49336 & 117376 \\
\hline 2018 & 47544 & 115487 \\
\hline 2017 & 44995 & 116287 \\
\hline 2016 & 42570 & 114672 \\
\hline 2015 & 41836 & 112376 \\
\hline 2014 & 41587 & 111457 \\
\hline 2013 & 40969 & 110829 \\
\hline 2012 & 41016 & 109379 \\
\hline 2011 & 39353 & 107269 \\
\hline 2010 & 38862 & 107897 \\
\hline
\end{tabular}




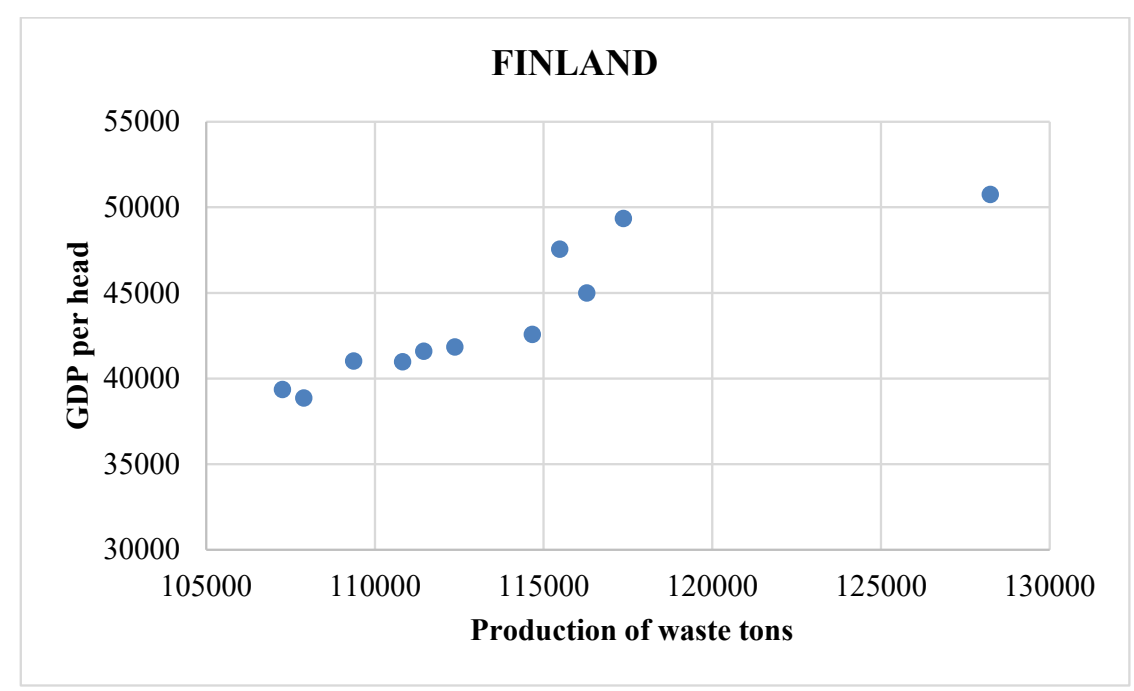

GDP $=0.62 \cdot$ Prod.waste -27459.4

The coefficient of correlation $=0.9$ and the coefficient of determination $=0.82$ are high enough and indicate a close linear connection between the variables. The independent variable coefficient is statistically significant with $=0.0001$

THE USA

\begin{tabular}{|c|c|c|}
\hline Year & GDP per capita (dependent), USD & Production of waste tons (the independent variable) \\
\hline 2020 & 20807 & 243158 \\
\hline 2019 & 21433 & 242967 \\
\hline 2018 & 20611 & 242935 \\
\hline 2017 & 19542 & 242055 \\
\hline 2016 & 18745 & 237782 \\
\hline 2015 & 18238 & 243471 \\
\hline 2014 & 17527 & 231380 \\
\hline 2013 & 16784 & 230158 \\
\hline 2012 & 16197 & 230006 \\
\hline 2011 & 15542 & 299567 \\
\hline 2010 & 14992 & 298637 \\
\hline
\end{tabular}

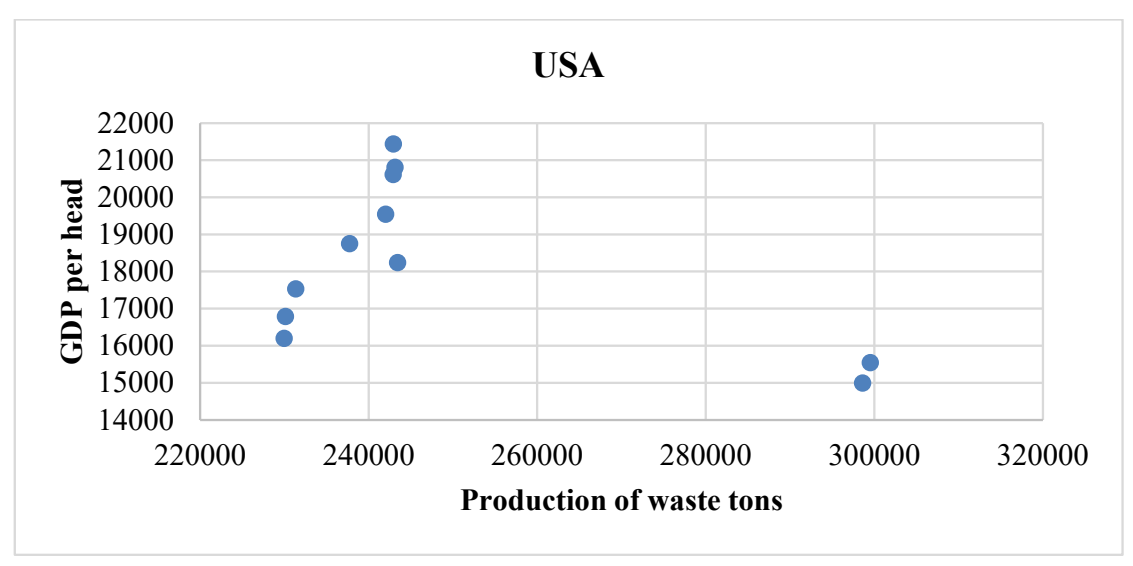

GDP $=0.62 \cdot$ Prod.waste -27459.4

The coefficient of correlation $=0.5$ and the coefficient of determination $=0.25$ are low enough and indicate the absence of a linear connection between variables. The diagram shows that the production of waste in the first two years of research was rather high and can be regarded as emissions, taking the given figures into account, that allows to conduct further analysis without the period between 2010 and 2011. In other cases, there is a linear trend's presence. The independent variable coefficient is statistically insignificant with $\mathrm{p}$-value $=0.11$ 